\title{
The Role of Timorese Women in Food Management
}

Komunitas: International Journal of Indonesian Society and Culture 9(2) (2017): 184-190

DOI:10.15294/komunitas.v9i2.10023

(C) 2017 Semarang State University, Indonesia p-ISSN 2086 - 5465 | e-ISSN 2460-7320

http://journal.unnes.ac.id/nju/index.php/komunitas

UNNDS JOURNALS

\section{Dhanang Puspita ${ }^{1,2}$, Maria M.Oematan 2, Dani Elimelek Fuka ${ }^{2}$, ${ }^{3}$ Theresia Pratiwi Elingsetyo Sanubari}

\author{
${ }^{1}$ Teknologi Pangan, Universitas Kristen Satya Wacana, Salatiga, Indonesia \\ ${ }^{2}$ Magister Biologi, Universitas Kristen Satya Wacana-Salatiga \\ ${ }^{3}$ IImu Gizi, Universitas Kristen Satya Wacana-Salatiga
}

Received: March 2016; Accepted: August 2016; Published: September 2017

\begin{abstract}
Timorese people have made gender segregation for several things such as; sex, traditional house and job. Timorese women are identical to round houses (ume kbubu), where inside the house, the women spend their time and activities. Timorese women play an important role in ume kbubu, one of which is the management of food. The purpose of this research is to investigate the role of Timorese women in food management. This research was conducted in Binaus Village, Molo Tengah District, South Central Timor Regency, West Nusa Tenggara Province. This research employed qualitative descriptive method from observation and interview. Timorese entitlement receives rights and responsibilities related to food management. They will arrange all streams of incoming and outgoing food. The conclusion of this research is that Timorese women have full control over family food management.
\end{abstract}

\section{Keywords}

food; gender; ume-kbubu; Timorese; women

\section{INTRODUCTION}

The life of Indonesian society has always been dominated by the life of Javanese society. Javanese community establishes high harmony that ultimately generates the concept of gotong royong (mutual cooperation) (William 1991 in Wade and Wilosa 2016). The construction of role between men and women is shaped due to Government of Indonesia which mostly uses the values of Javanese community and values of Islam. In the family work, women must be loyal to her husband and is expected to be the ideal housewife and mother (Ida 2001). The public expectation of mothers who become the ideal household figure is unfortunately not reaching the food management affairs wit- hin a family. The concept of an ideal mother becomes visible when it is associated with the mother's role within the food system including the material, social, and physical sectors. Women, in term of material things, are more often focused on women as productive labor. Under socio-cultural terms, women are more often discussed in terms of physical reproduction. And lastly, within physical term, women are associated with the food and dietary (Allen \& Sachs 2007; Kimura et al. 2009; Ibnouf 2009).

The construction concept, which is supported by the government of this count-

\footnotetext{
Corresponding author

Jl. Diponegoro 52-60 Salatiga - Indonesia 50711 Email

dhanang.puspita@staff.uksw.edu
} 
ry, makes the distance between the roles of men and women is widening. Nevertheless, women>s participation in family food management is always discussed as an ideal but remains a far-reaching concept to achieve. Arsal (2015) in his research, "The involvement of women in the production of emping melinjo (melinjo chips) to improve the economy of the rural farmer household", shows that women assist in the production of emping melinjo as a routine and help their husbands to improve the family economy. On the other hand, the company only values men >s work but not women. Dina \& Yayuk (2016) in «The Role of Women in Family Food Security» discusses the role of women in food security which is very important but is often overlooked because it is only considered a routine. This study also becomes incompatible if it is associated with the construction of gender in Timorese society (Atoin meto) which has the concepts of abit mone and abit ume. Abit mone is interpreted as men who are working outside to earn a living for his family. Abit ume is a guardian to keep the house, which is the term for women who do various activities of household.

Geographically, the island of Timor which is dry has made people think hard in living their lives. Women have an important role in maintaining the survival of their families with regard to the fulfillment of food. Although men are the providers of food, women are under heavy duty in regulating the entry of food outflows from the harvest to the next harvest. Women are also responsible for managing stored food for almost 1 full year. The decision to take how much food is stored is all determined by women. The Timorese society forbids men and children from getting in touch with food because they think only women can touch it. This research employed qualitative descriptive method using interview and observation in Binaus Village. The purpose of this study is to investigate the role of Timorese women in food management in Timorese society.

This research employed qualitative descriptive method. The data was ob- tained by interview and observation in the field. The study was conducted in Binaus Village, North Molo District, South Central Timor Regency, East Nusa Tenggara Province and took place in August 2016.

\section{GENDER SOCIETY OF TIMOR SOCIETY}

Gender symbolization in Timor is not only related to sex and house, but also refers to the type of food they consume. Corn is the staple food of Timorese society. In the cultural point of Timorese society, corn is regarded as Usif or king and is called as Atoin mone or male. Corn is a symbol of physical strength that is capable of generating power for Atoin meto. Rice, for Timorese people, is a symbol of femininity which called as li feto. They consider rice as women because they have no power. Corn as a staple food becomes their main crop because it becomes a primary food requirement. The obstacles that arise are the planting season that comes only once a year and the condition of the soil that is not too fertile. The season and condition of the land on Timor Island is related to its geographical location.

The island of Timor, located in the province of East Nusa Tenggara, has a climate which is influenced by wet west monsoon winds in November - April, and dry eastern weather in May - October. The locations of Timor Island which are adjacent to Australia will experience longer dry season with little rainfall (Mundita 2013). The geographical and climatic conditions will affect agriculture, thereby allowing only one planting season at the time of the rainy season. Agricultural cultivation is also not as many as other areas such as Java and Sumatra Islands with fertile areas due to volcanoes. Timor Island with barren and less fertile land implements dry land agriculture such as in gardens or fields (Sasi 2016). Types of cultivated plants are plants that have been adapting to Timor Island, such as corn and beans.

The number of crops and harvest that only comes once a year makes people create a strategy to maintain food security. In order to maintain food security, the role of women is very pivotal. Women are in full control 
of post-harvest food management until the next harvest comes. Women will maintain the availability of foods supply stored in a barn in ume kbubu. Timorese society considers men and children to be extremely taboo when it comes to food stored inside ume kbubu. Women will be privileged with regard to the management of food. Besides managing the food, East Timorese women are fully responsible for the flow of both incoming and outgoing food supply in order to maintain the availability of food, especially during lean times.

\section{UME KBUBU AND WOMEN TIMOR}

Symbols always appear in human life, as well as the existing gender concepts in society. The symbol in gender is always identified with masculinity (male) and femininity (female). The examples of the use of the symbol are blue, Mars, and square for men; and pink, Venus, and circles for females. This symbol also appears in ume kbu$b u$. Ume kbubu is a round warehouse with a roof made of reeds, as shown in Figure 1 (left). A family shall have umu kbubu before having other types of houses (Saunoah et al. 2006).

Abit mone and abit ume are not just the name for both men and women but also affect its role in society. This role also emerges from ume Kbubu or houses owned by Atoin meto or Timorese society. Ume $k b u b u$ is associated with women who are feminine with humble attitude. Ume kbubu must be owned by every family and becomes the main house. Ume kbubu is the center of family activities and the role of women/mothers is very prominent. And the male role is Lopo that symbolizes the male role as a symbol of protection and guidance for the occupants (Karwur et al. 2016).

Ume kbubu is considered as a symbol of femininity because ume kbubu takes part in the family life of Timorese people. In their gender roles, a woman is as the protector of the family. Women mostly live in the house to take care of their home as compared to men who have to earn a living outside their house. Ume Kbubu, as the main house, is used as the family's kitchen, bed, and storing food. Therefore, it becomes the domestic symbol.

Ume kbubu complements its role in bo'ha neno tradition. The tradition of Bo'ha neno is a tradition reserved for women after giving birth in ume kbubu for 40 days with the baby they bore. For 40 days, the woman should only eat corn bose, which is corn boiled with beans. This tradition is still practiced until today, one of which is in the Binaus Village, although there are people who are leaving this tradition.

Women in Timor Island cannot be separated from ume kbubu. Ume kbubu is attached to women as a symbol and the construction of the role of women in all the activities in Timor Island. Women will

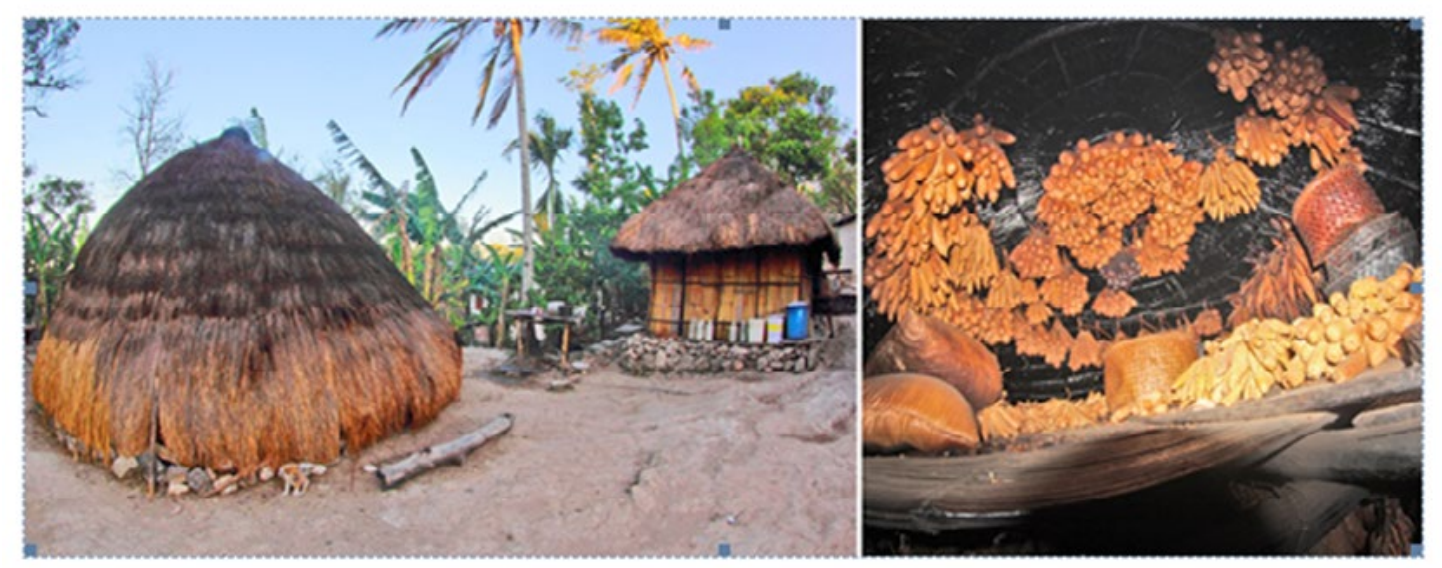

Figure 1. Ume kbubu and box home (left), warehouse storage in the attic of ume yields $k b u$ bu (right). 
spend much of their time in Ume Kbubu such as preparing groceries, cooking, serving, and keeping the fireplace.

\section{FOOD MANAGEMENT IN UME KBUBU}

Food management is utilizing an effective food to achieve the desired goals. Agriculture on Timor Island only allows harvesting once a year because of the seasons. The planting season begins before the rainy season in November - December and will harvest in March - April. There is a period of $4-5$ months from planting to harvest.

The types of cultivated plants are also not diverse. Timor people choose local plants that already have the ability to adapt themselves to a dry environment. The types of crops such as cassava, corn, rice and tubers become the main choices. The supporting crop is the type of beans. Such types of plants are developed over generation.

In the agricultural context, men served in the fields for preparing the land, planting, cultivating plant and harvesting while women serve only to support them. When the harvest time arrives, the men will bring the harvest and put it in front of the door of ume kbubu. The processes of food storing from the door to the ume kbubu and until further processing belong to women. In Timor, men are nanuin or taboo to enter ume kbubu when women are working on the harvest. This stage indicates that women have full rights to work on the harvest given to them.

Women, in this case the mother or wife, could be working on crops such as rice, corn, and beans. There is food management applied by Timorese women associated with the setting of the crop. The purpose of this food management is to regulate the flow of the crops for daily consumption, savings, and food reserves until the next harvest. This stage also indicates that women have full rights in harvest regulators for their families.

The management of crops made entirely by women from receiving the harvest is an interesting phenomenon. In the relationship between food security and gender, women are often the disadvantaged. In many cases, women are the ones who are more often unmet for their nutritional needs because they do not have the time and access to an active process food, farming and services for the asset (Azahari 2008; Yunindyawati et al. 2014; Martin \& Lippert 2012; Harper et al. 2013).

Timorese people give women an active role in processing food which means Timorese women have the opportunity to offer what they want and do not want to eat. However, this research has not been depicting the cultural forms that are owned by the people of Timor. Cultural forms can play a role in decision making. Cultural demands can make women, especially women in poor condition, not to fulfill their need for nutrition because they prioritize their children and their husbands condition.

Corn for the people of Timor which is seen as Usif or king will get preferential treatment from women. In the management of crops, corn will be served in two types, i.e. corn will be stored with its skin (klobot) and without its skin. Corn stored with skin that is covered will be used for consumption into the pen pasu. Pen pasu refers to the process of cooking corn seeds by directly boiling it. Corn stored without skin will be consumed into a pen bosu. Pen bosu is cooking corn seeds by removing the epidermis by grinding and after that, it is boiled.

The corn storage is done by bonding and putting it in the attic of ume kbubu, as shown in Figure 1 (right). Number of corn ties in one bundle is the multiplication of 6 cobs. One bundle consists of 6 cobs which are united to be 2 bunches. Therefore, there are 12 cobs and called nimaf. For the bond which contains 24 cobs, it is called aisut and 36 cobs called a suku. Not only the amount, the size of cob is also made the same. With the storage of corn groupings based on quantity and size, they have been able to predict the size of food needs for the foreseeable future, even until harvest time comes again or there are some that can be sold or bartered.

The goal in the binding of corn in 
such numbering system is to facilitate the calculation or as an inventory check. Therefore, at any moment, it can be easily known to its availability. The binding also makes it easier when corn owners are about to sell or barter their corn because the value of corn used is the unit; nimaf, aisut, and tribes. In addition to sell or to barter, corn that has been tied can also be used as goods for donations for marriage, sorrow, traditional parties, religious party, and so forth. The amount of donations is based on nimaf, aisut, and tribes.

The entry of corn from ume kbubu will be regulated by women. Men and children should not touch the corns which have been stored in kbubu ume. Soni Sanam (36 years old) tells if the husband can only deliver crops such as corn just to the front door of kbubu ume. After that, she would enter the room by bringing the corn, binding, and store it in kbubu ume. Only women can take, organize and move the corn in ume kbubu. They really entrust this food warehouse to women, so women really have a vital role in food affairs. The management of food products must be carried by only one woman and cannot exceed that amount. Those women can be wife, mother or grandmother. In terms of Timorese language, it is called nimaf mese (one hand). The Kase family is an example. The management of food is left entirely on Milka Kase ( 88 years). She is the oldest woman of the Kase family, despite having a son and a daughter-in-law, but the management of food is in her hands.

Timorese value who entrusts only one woman to food management indicates good managerial system. They will not provide management affairs to more than one person because it can lead to mismanagement and dissent. They also believe that if there is a new member in their family, such as a wife entering a male family, she should not touch food or an accident will arise. This prohibition shows that they still maintain kinship and the power of the nuclear family in the management of food. Core families are believed to be more able to understand the dynamics of family food needs than those new to the family.

According to the Timorese belief, if their food management is done by more than one woman, food supply will decrease in number. Especially for a woman who has been married and has made the process of family moving to follow her husband s clan (kaos nono), they are not allowed to take
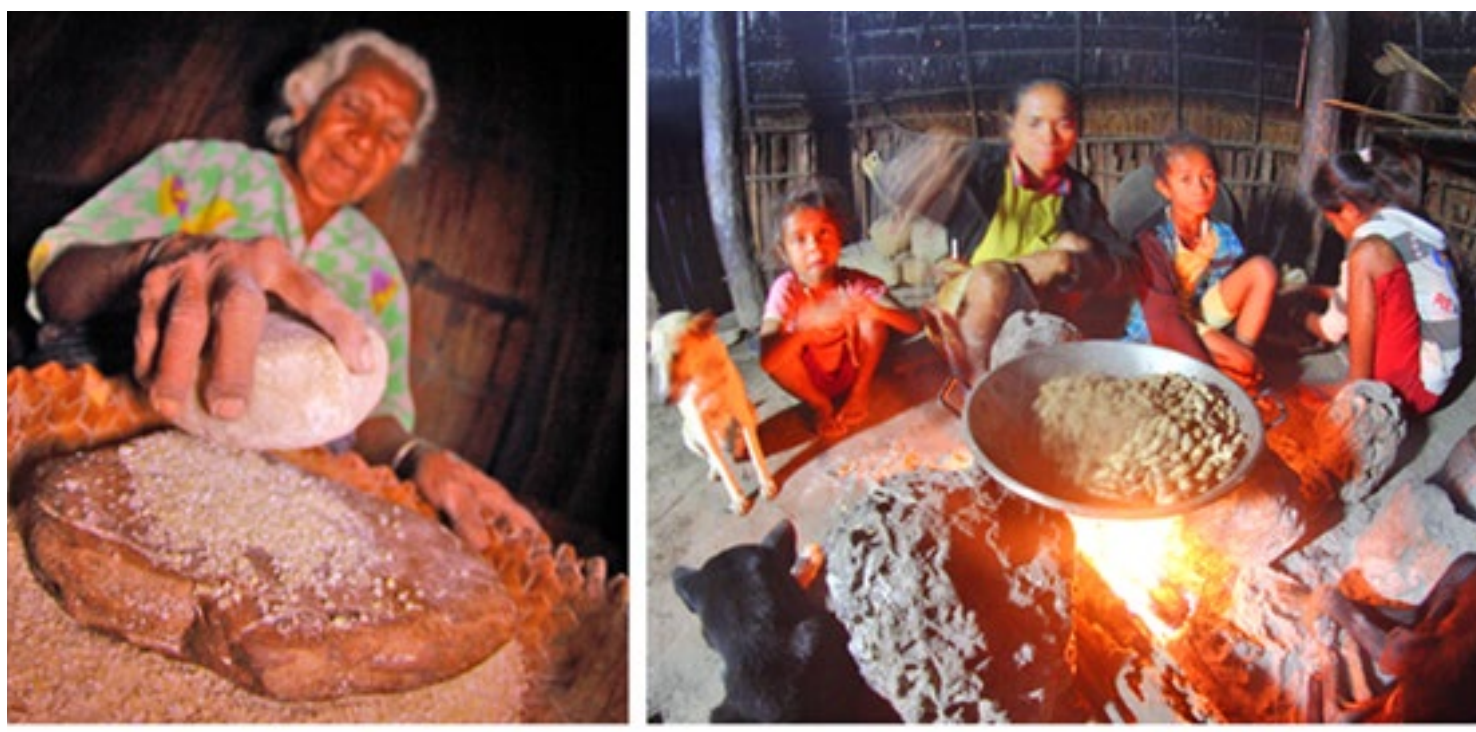

Figure 2. There should be only one woman who will organize and process the food. Picture left is Milka Kase (88), a mother or grandmother who becomes a manager. And the right picture is the wife who becomes manager of Kase family. 
food in kbubu ume. In violation of such matters, they may cause problems in their domestic life, for example: sickness, death, or disability of their children.

In daily consumption, women will decide what type of food to be cooked. Based on the calculation of the crop and food supply in kbubu ume, eating foods in the daily menu is already taken into account long ago. Families with wide fields and abundant crops will not be too concerned about the availability of food, but those with narrow fields and limited crops will be really strict about their food.

In one day, the people of Timor will eat three times, i.e. morning, noon, and night. Their main consumption is corn, but there are other varieties such as cassava, sweet potatoes and rice. Like the Javanese people who consider they have not eaten if they have not eaten rice, for Timorese people, they have not eaten if they have not eaten corn. The tradition of this diet makes them have to try to meet the needs of corn.

For those who have a supply of corn, it is not too much to diversify the types of daily food consumption. In the morning, women will cook corn mixed with beans. During the day will cook cassava or sweet potatoes. In the evening, it will be back to cook corn. There is also a modified corn cooked with rice to provide a variety of flavors.

The purpose of this diversity of cuisine does not merely provide color and flavor in cooking, but also in the effort to save or keep corn availability. Timorese women will think hard how to seek the ways to continue cooking and having availability of corn remain which is safe until the harvest arrives.

\section{CONCLUSION}

Timorese women have full control over family food management. In one large family, only the oldest woman (grandmother, mother, or wife) can manage the food. They will arrange all the crops, put inside, calculate, store and manage it until the next harvest arrives. To help calculating the amount of harvest of nimaf, aisut and suku, they will bind the corn by the multiplication of 6,12 , and 36 . The purpose of this binding is to estimate food availability within a certain time and to ease them in calculating the yields and supply which are still available. Men and children are prohibited from touching the stored food. Women are responsible for the management of food, even though the men are the one who fulfill it.

\section{REFERENCES}

Allen, P., Sachs, C., 2007. Women and Food Chains: The Gendered Politics of Food. Int J Sociol Food Agric. 15(1), pp.1-23.

Arsal, T., 2015. The Involvement of Women in the Production of Emping Melinjo (Melinjo Chips) to Improve the Economy of Rural Farmer Household. Komunitas: International Journal of Indonesia Society and Culture. 7(2), pp.243-250.

Azahari, D. H., 2008. Indonesia Rural Women: The Role in Agricultural Development. Analisis Kebijakan Pertanian. 6(1), pp.1-10.

Charlesworth, H., 2008. Are women peaceful? Reflections on the role of women in peace-building. Feminist Legal Studies, 16(3), pp.347-361.

Hall, N., 2009. East Timorese women challenge domestic violence. Australian Journal of Political Science, 44(2), pp.309-325.

Harper, S., Zeller, D., Hauzer, M., Pauly, D., \& Sumaila, U.R., 2013. Women and fisheries: Contribution to food security and local economies. Marine Policy, 39, pp.56-63.

Ibnouf, F.O., 2009. The role of women in providing and improving household food security in Sudan: Implications for reducing hunger and malnutrition. Journal of International Women's Studies, $10(4)$, p.144.

Ida, R., 2014. The Construction of Gender Identity in Indonesia: Between Cultural Norms, Economic Implications, and State Formations. Masyarakat, Kebudayaan, dan Politik, pp.21-34.

Karwur, F.K., Saekoko,Y.F, Tauho, K.D., 2016. Binaus (Ume Kbubu di Dusun II Desa Binaus). Satya Wacana University Press, Salatiga.

Kent, L., 2011. Local memory practices in East Timor: Disrupting transitional justice narratives. International Journal of Transitional Justice, 5(3), pp.434-455.

Kimura, A., Wada, Y., Goto, S.I., Tsuzuki, D., Cai, D., Oka, T., \& Dan, I., 2009. Implicit genderbased food stereotypes. Semantic priming experiments on young Japanese. Appetite, 52(2), Pp.521-524.

Martin, M.A., \& Lippert, A.M., 2012. Feeding her children, but risking her health: The intersection of gender, household food insecurity and obesity. Social science $\mathcal{E}$ medicine, 74(11), pp.1754- 
1764.

Milka, K., 2016. Wawancara Pribadi.

Mundiata, I.W., 2013. Pemetaan Pangan Lokal di Pulau Sabu-Raijua, Rote-Ndao, Lembata, dan Daratan Timor Barat. Perkumpulan Pikul Kupang, Kupang.

Neto, F., Furnham, A., \& da Conceição Pinto, M. 2009. Estimating One's Own and One's Relatives' Multiple Intelligence: A cross-cultural study from east Timor and Portugal. The Spanish journal of psychology, 12(2), pp.518-527.

Priminungtyas, D.N., \& Yuliati Y., 2016. Peran Perempuan Dalam Ketahanan Pangan Keluarga. Seminar Nasional Pembangunan Pertanian. Universitas Brawijaya Malang, Malang.

Puspitawati, H. 2013. Konsep, Teori dan Alisisi Gender. Departemen Ilmu Keluarga dan Konsumen. Fakultas Ekologi Manusia-Institut Pertanian Bogor, Bogor.

Sasi, D., 2016. Perubahan Budaya Kerja Pertanian Lahan Kering Atoni Pah Meto di Kabupaten Timor Tengah Utara. Paradigma Jurnal Kajian Budaya. 6(2), pp.145-164.

Saunoah, H., Tallan, J.M., Subani, M,. 2006. Lopo
Representasi Sistim Budaya Atoin Meto TTU. Dinas Kebudayaan dan Pariwisata Kabupaten Timor Tengah Utara, Kefamenanu.

Soni Saman. 2016. Wawancara Pribadi.

Wade, J.C. and Wiloso, P.G., 2016. Religiosity, masculinity, and marital satisfaction among Javanese Muslim men. International Journal, 5(3), pp.37-52.

Wigglesworth, A., 2016. Dreaming of a Different Life: Steps towards Democracy and Equality in Timor-Leste. Journal of Lusophone Studies, 10.

Wild, K., Barclay, L., Kelly, P., \& Martins, N., 2010. Birth choices in Timor-Leste: a framework for understanding the use of maternal health services in low resource settings. Social science $\mathcal{E}$ medicine, 71(11), pp.2038-2045.

Yunindyawati, Sumarti T, Adiwibowo S, Vitayala A, Hardinsyah. The Power of Women's Knowledge in Food Security at the Rural Families in Indonesia (The Case in South Sumatera). International Journal of Humanities and Social Science. 4(7), pp.308-313. 